\title{
Apple juices from ancient Italian cultivars: a study on mature endothelial cells model
}

\author{
Francesca Felice $^{1, \star}$, Esther Maragò ${ }^{2, \star}$, Luca Sebastiani $^{2, \star \star}$ and Rossella Di Stefano ${ }^{1,3}$ \\ 1 Cardiovascular Research Laboratory, Department of Surgical, Medical, Molecular and Critical Area Pathology, University of Pisa, Italy \\ 2 BioLabs, Institute of Life Sciences, Scuola Superiore Sant'Anna, Pisa, Italy \\ 3 Interdepartmental Research Center "Nutraceutical and Food for Health", University of Pisa, Italy
}

Received 13 May 2015 - Accepted 24 July 2015

\begin{abstract}
Introduction. Endothelial cell death due to increased reactive oxygen species (ROS), contributes to the initial endothelial dysfunction, which promotes atherosclerotic lesions. Several fruit products, including apple and apple juice (AJ), are reported to be beneficial for humans' health. However, the protective effect of different kind of apples and particularly ancient varieties remain unknown. This study aimed to investigate the effects of three Italian local ancient variety AJ on human umbilical vascular endothelial cells (HUVECs) model system. Materials and methods. Antioxidant activity and phenolic content were determined in 'Nesta', 'Panaia-red' and 'Cipolla' Italian local ancient variety AJ. 'Golden Delicious' variety AJ was used as control. HUVECs were treated for $24 \mathrm{~h}$ with various concentrations in total polyphenols of AJ (5-50-100 $\left.\mathrm{mg} \mathrm{L}^{-1}\right)$ and then with $2 \mathrm{mM}$ of $\mathrm{H}_{2} \mathrm{O}_{2}$ for $1 \mathrm{~h}$. Cytotoxicity and ROS production were evaluated as appropriate. Results and discussion. 'Panaia-red' AJ showed strong antioxidant capacity and a higher content in total polyphenols compared to 'Cipolla', 'Nesta' and 'Golden Delicious' varieties. Moreover, 'Panaia-red' AJ pretreatment significantly improved cell viability and resistance to oxidation $(P<0.05)$. Conclusion. The results of our study might be useful to revalue ancient Italian apple varieties and to develop new apple-based products with health beneficial properties.
\end{abstract}

Keywords: Italy / apple / Malus domestica / antioxidant activity / phenolics / oxidative stress / genetic resources

Résumé - Jus de pomme d'anciens cultivars italiens : étude d'un modèle de cellules endothéliales matures. Introduction. La mort des cellules endothéliales provoquée par une augmentation des espèces réactives de l'oxygène (ROS) contribue au dysfonctionnement endothélial initial, ce qui favorise les lésions athérosclérotiques. Plusieurs produits issus de fruits, y compris les pommes et le jus de pomme (AJ), sont signalés pour être bénéfiques pour la santé humaine. Cependant, l'effet protecteur de types différents de pommes et particulièrement des variétés anciennes est inconnu. Cette étude vise à étudier les effets du jus de trois anciennes variétés italiennes de pommes sur les cellules endothéliales vasculaires ombilicales humaines (HUVEC) utilisées comme système modèle. Matériel et méthodes. L'activité antioxydante et la teneur phénolique ont été déterminées dans les jus des pommes 'Nesta', 'Panaia-rouge' et 'Cipolla', anciennes variétés de terroir italiennes. Le jus de la variété 'Golden Delicious' a été utilisé comme témoin. Les cellules HUVEC ont été traitées pendant $24 \mathrm{~h}$ avec diverses concentrations de polyphénols totaux des jus (5-50$100 \mathrm{mg} \mathrm{L}^{-1}$ ), puis avec $2 \mathrm{mM}$ de $\mathrm{H}_{2} \mathrm{O}_{2}$ pendant $1 \mathrm{~h}$. La cytotoxicité et la production de ROS ont ensuite été évaluées. Résultats et discussion. Le jus de 'Panaia-rouge' a montré une forte capacité antioxydante et une teneur plus élevée en polyphénols totaux comparativement aux variétés 'Cipolla', 'Nesta' et 'Golden Delicious'. En outre, le prétraitement du jus de 'Panaia-rouge' a amélioré de manière significative la viabilité des cellules et de leur résistance à l'oxydation $(P<0,05)$. Conclusion. Les résultats de notre étude pourraient servir à réévaluer l'intérêt des anciennes variétés de pommes italiennes et à développer de nouveaux produits à base de pomme avec des propriétés bénéfiques pour la santé.

Mots clés : Italie / pommier / Malus domestica / activité antioxydante / composés phénoliques / stress oxydatif / ressources génétiques

$\star$ These authors contributed equally to the work.

$\star \star$ Corresponding author: luca.sebastiani@sssup.it 


\section{Introduction}

Diet plays a key role in the prevention of chronic diseases. This is demonstrated by several epidemiological studies [1,2]. Nowadays, nutrition research shows that a diet rich in fruit and vegetables is strongly associated with the risk reduction of cancer, diabetes, cardiovascular and Alzheimer's disease and age-related functional decline [3]. Oxidative stress plays an important role in the pathogenesis of various cardiovascular diseases [4]. Oxidative stress results from the imbalance between the pro-oxidant and the antioxidative defence mechanisms of the body. At high concentrations, reactive oxygen species (ROS) can cause severe damage to cellular structures and components including nucleic acids, proteins, and lipids, thereby leading to cell death [5].

The endothelial cells that line the blood vessels are very sensitive to injury caused by oxidative stress. Endothelial cells play an important role in physiological hemostasis, blood vessel permeability, and response of blood vessel to other physiologic and pathologic stimuli [6]. Any abnormality in endothelial cell structure and function may contribute significantly to blood vessel diseases such as thrombosis, atherosclerosis, and vasculitis.

Plant foods contain a variety of bioactive compounds including flavonoids and others polyphenols. Apple (and apple juice, $\mathrm{AJ}$ ) is one of the most commonly and consumed fruits worldwide and represent a main source of vitamins and minerals. In the United States and Europe apple is one of the major edible fruits. In fact, in the United States, apples deliver $22 \%$ of the phenolics consumed from fruits, making them the largest source of phenolics. Also in northern Europe, especially in Finland and Netherland, apples are a very good source of polyphenols, together with onions [2]. Italy is the sixth apple producer country in the world with more than 1.9 million tons of apples per year and the third exporter country after China and Poland (data from World Apple and Pear Association - WAPA). The top-producing apple cultivar worldwide, and particularly in Italy, is 'Golden Delicious'. There are lots of ancient apple varieties that have a higher content of phytochemicals in comparison with the most commercial one [7-9]. Generally, these ancient varieties are marketed only in the local areas of production and their sale and consumption are very important for the local population. Moreover, apples are rich in phenolic compounds [10], that are widely discussed as promising candidates for prevention of cancer and inflammation $[2,11]$. Apple and AJ are reported to increase antioxidant levels in humans [12] and have been tested as cancer chemopreventive both in vitro [13] and in humans $[14,15]$. Beside cancer chemoprevention, apple polyphenols have been reported to have other in vitro and in vivo physiological properties, such as antiallergenic and anti-caries activity, and inhibitory activity against some enzymes and receptors involved in pathological processes $[2,16]$.

Many factors influence the complexity of the phytochemical profile of apple and those variations predispose the differences in apple antioxidant activity. Studies aimed at comparing total polyphenols in commercial and ancient apple cultivars showed that cultivar effects on phenolic compounds can be relevant as total polyphenol content range between 56 and $221 \mathrm{mg}$ GAE $100 \mathrm{~g}^{-1}$ fresh weight in commercial and ancient cultivars ('Panaia-red') respectively $[8,17]$ proving the wide apple genetic variability for polyphenol trait.

Aim of the present study was to characterize the apple juice from three Italian ancient cultivars in comparison to a commercial and widely diffused one ('Golden Delicious') determining their antioxidant compounds and their protective effects on the hydrogen peroxide $\left(\mathrm{H}_{2} \mathrm{O}_{2}\right)$-induced oxidative cell damage in cultured human umbilical vein endothelial cells (HUVEC).

\section{Materials and methods}

\subsection{Fruit material}

The apple (Malus $x$ domestica Borkh) genotypes studied were three ancient cultivars ('Nesta', 'Panaia-red' and 'Cipolla') in comparison with a commercial one ('Golden Delicious'). 'Nesta', 'Panaia-red' and 'Cipolla' are ancient Tuscan variety [18] known and cultivated especially in the Casentino area [19]. These local varieties have been catalogued and described in the Regional repertories of Tuscany (http://germoplasma.arsia.toscana.it/germo/), which represent the basic tool of the protection system for regional autochthonous genetic resources and actions are in progress for the valorisation of this variety [20].

Apple plants were grown in the same orchard in the Casentino area (Arezzo,Tuscany, Italy) and fruits were harvested at commercial maturity. Cultivation techniques followed the good farming practices established locally for low-input integrated farming system. The investigation was run in 2011. The optimal harvest period was since the end of September for 'Golden Delicious' to the end of October for 'Nesta', 'Panaia-red' and 'Cipolla'. Three independent biological replicates of each cultivar were done: each biological replicate was made up of 4 apple fruits, sampled randomly from a bulk of independent harvests of $10 \mathrm{~kg}$ apple each.

\subsection{Chemicals}

Ascorbic Acid, Gallic acid, (+)-Catechin, (-)-Epicatechin, Chlorogenic acid, Neo-chlorogenic acid, Phloridzin, Procyanidin $\mathrm{B}_{1}$, Folin-Ciocalteau reagent, 1,1-diphenyl-2picrylhydrazyl (DPPH 90\%) were purchased from Sigma Aldrich (Milan, Italy). All chemicals were of analytical or HPLC grade and the aqueous solution were prepared by using ultra-pure water purified by Milli-Q System (Millipore, Milan, Italy).

\subsection{Physiochemical parameters determination}

Soluble solids content (SSC) and titratable acidity (TA) were measured in apple fruit. SSC was determined by a handheld refractometer (Sper Scientific, AZ, USA), and results expressed as ${ }^{\circ}$ Brix. TA was determined by titrating $10 \mathrm{~mL}$ juice with $0.1 \mathrm{~N} \mathrm{NaOH}$ to $\mathrm{pH} 8.1$ using $1 \%$ phenolphthalein, and results are given as malic acid equivalents (MAE) $\mathrm{L}^{-1}$. The $\mathrm{pH}$ was measured by a $\mathrm{pH}$-meter and results are expressed as $\mathrm{pH}$ units. 


\subsection{Preparation of apple juice}

After harvest, fruits were washed, chopped into pieces and apple juice (AJ) was prepared using a domestic centrifuge for the production of fruit and vegetable juices (Vita Pro-Active, mod. JE810, Kenwood electronic, Havanthants, UK). Immediately after preparation the $\mathrm{AJ}$ was divided into $120 \mathrm{~mL}$ aliquots in glass bottles. All bottles were pasteurized at $80{ }^{\circ} \mathrm{C}$ for $30 \mathrm{~min}$ and stored in a dark-room at room temperature (RT). Analyses were performed on juices after preparation and after four weeks of storage. Apple juices were filtered prior analyses at $0.45 \mu \mathrm{m}$.

\subsection{Total phenolics and flavonoids}

Total phenolic content (TP) of AJ was measured using the Folin-Ciocalteu assay with some modifications to reduce volumes [21]. TP content was expressed as mg gallic acid equivalents (GAE) $\mathrm{L}^{-1}$ juice. Total flavonoid content (TF) of AJ was determined using a colorimetric assay [22] and expressed as $\mathrm{mg}$ catechin equivalents (CE) $\mathrm{L}^{-1}$ juice.

\subsection{HPLC for phenolics composition and ascorbic acid}

HPLC was performed on AJ immediately after preparation (T0) and after four weeks of storage (T1) using a series 1200 HPLC instrument (Agilent Technologies, Palo Alto, CA) equipped with ChemStation software (B.03.01), a model G1379B degasser, a model G1312B binary gradient pump, a model G1367C thermoautosampler, a model G1316B column oven, and a model G1315C diode array detection system. For identification and quantification of phenolic compounds, separations were achieved on a ZorbaxEclipseXDB-C18 $(50 \times$ $4.6 \mathrm{~mm} ; 1.8 \mu \mathrm{m}$ particle size). The mobile phase flow rate was fixed at $0.5 \mathrm{~mL} \mathrm{~min}{ }^{-1}$. For the gradient elution water $+0.1 \%$ formic acid (A), and acetonitrile $+0.1 \%$ formic acid (B) were used as mobile phases. The gradient started with $5 \% \mathrm{~B}$ to reach $10 \% \mathrm{~B}$ at $5 \mathrm{~min}, 40 \% \mathrm{~B}$ at $20 \mathrm{~min}, 90 \% \mathrm{~B}$ at $25 \mathrm{~min}, 90 \% \mathrm{~B}$ at $29 \mathrm{~min}$. The detection was at $280 \mathrm{~nm}, 330 \mathrm{~nm}$ and $360 \mathrm{~nm}$. For identification and quantification of Ascorbic Acid, separations were achieved on a ZorbaxEclipseXDB-C18 $(300 \times 3.9 \mathrm{~mm}$; $10 \mu \mathrm{m}$ particle size). The mobile phase flow rate was fixed at $1 \mathrm{~mL} \min ^{-1}$. For the gradient elution water $+0.2 \%$ formic acid (A), and acetonitrile $+0.2 \%$ formic acid (B) were used as mobile phases. The gradient started with $5 \%$ B to reach $95 \%$ $\mathrm{B}$ at $12 \mathrm{~min}, 95 \% \mathrm{~B}$ at $18 \mathrm{~min}, 5 \% \mathrm{~B}$ at $24 \mathrm{~min}$. The detection was at $245 \mathrm{~nm}$.

AJ were filtered with a $0.2 \mu \mathrm{m}$ strainer prior to HPLC analysis to eliminate all solid particles. Moreover, they were diluted 1:1 for polyphenolic compounds analysis. Identification and quantification were carried out using external standards. All samples were assayed in triplicate.

\subsection{Antioxidant activity - DPPH}

This method was performed using DPPH [23], a stable free radical compound with a strong absorption at $515 \mathrm{~nm}$.
An aliquot of $0.077 \mathrm{~mL}$ of an appropriate dilution (1:5) of each apple juice was added to $3 \mathrm{~mL}$ of DPPH methanolic solution $\left(12 \times 10^{-5} \mathrm{M}\right)$, and vortexed. Absorbance at $515 \mathrm{~nm}\left(\mathrm{~A}_{515}\right)$ was measured at different time intervals on a UV-VIS Agilent HP 8453 diode array spectrophotometer until the reaction reached a plateau, in order to find the time required to achieve the steady state. The initial concentration of DPPH was controlled for every experiment by using a calibration curve made by measuring the absorbance at $515 \mathrm{~nm}$ of standard samples of DPPH at different concentrations. The equation of the curve was

$$
\mathrm{Abs}_{515}=0.0085 \times\left[\mathrm{DPPH}^{-}\right]\left(\mathrm{R}^{2}=0.99810\right)
$$

as determined by linear regression. The DPPH radical scavenging effect was expressed as percentage reduction (\%R) of the initial DPPH absorption operated by test samples:

$\% \mathrm{R}$ of the initial DPPH absorption $=$

$$
\left[\left(A_{\mathrm{DPPH}}\left(t_{0}\right)-A_{\text {sample }}(t)\right) / A_{\mathrm{DPPH}}\left(t_{0}\right)\right] \times 100
$$

where $A_{\mathrm{DPPH}}\left(t_{0}\right)$ is the absorbance of DPPH at zero time and $A_{\text {sample }}(t)$ is the absorbance of the solution added of the sample after time $t$. The DPPH scavenging capacity was evaluated through the analysis of the logarithmic curves obtained measuring the radical percentage reduction after 5, 20, 40, 60, 90 and 120 min of reaction.

\subsection{Cell culture and treatment}

HUVEC were isolated from fresh human umbilical cords by incubation with collagenase (Invitrogen, Auckland, New Zealand) and cultured on gelatine-coated flasks in Medium199 (Cambrex) containing 20\% heat-inactivated FBS (Cambrex), sodium heparin (Biologici Italia Laboratories, Milan, Italy), penicillin/streptomycin (Cambrex), HEPES (Cambrex), glutamine (Sigma, St. Louis,MO) and bovine retina-derived extract in a humidified atmosphere $\left(37{ }^{\circ} \mathrm{C}, 5 \% \mathrm{CO}_{2}\right)$. The $\mathrm{P} 4-\mathrm{P} 5$ cultures were cultivated until sub-confluence was reached. Thereafter, HUVEC were exposed to the different experimental conditions. Briefly, cells were pre-incubated for $24 \mathrm{~h}$ with different concentration of total polyphenols of three ancient cultivars AJ (5-50-100 $\left.\mathrm{mg} \mathrm{L}^{-1}\right)$. The dilutions were prepared in pure M199 medium. 'Golden Delicious' AJ was used as control. Then, cells were treated with $2 \mathrm{mM} \mathrm{H}_{2} \mathrm{O}_{2}$ for $1 \mathrm{~h}$. At the end of treatment, cells were washed twice with PBS and analysed for cytotoxicity and production of reactive oxygen species (ROS).

\subsection{Cell viability}

Cell viability was evaluated by WST-1 assay, a colorimetric assay based on the cleavage of tetrazolium salt (WST-1, 4-[3-(4-Iodophenyl)-2-(4-nitrophenyl)-2H-5-tetrazolium]-1,3benzene disulfonate, Roche Applied Science, Mannheim, Germany) by mitochondrial dehydrogenases in viable cells. Briefly, after treatment, HUVECs were incubated with tetrazolium salt $\left(10 \mu \mathrm{L}\right.$ well $\left.{ }^{-1}\right)$ for $4 \mathrm{~h}$ at $37{ }^{\circ} \mathrm{C}, 5 \% \mathrm{CO}_{2}$. Then, the formazan dye formed was quantified by measuring the optical density at $450 \mathrm{~nm}$ (reference wavelength: $650 \mathrm{~nm}$ ) by use of a multiplate reader (Titertek). The absorbance directly correlated with the number of metabolically active cells. 
Table I. Physiochemical parameters of 'Nesta', 'Panaia-red', 'Cipolla' and 'Golden Delicious' cultivar after apples harvest.

\begin{tabular}{lcccc}
\hline & \multicolumn{4}{c}{ Physiochemical Parameters } \\
\cline { 2 - 5 } $\begin{array}{l}\text { Apple fruit } \\
\text { cultivars }\end{array}$ & $\begin{array}{c}\text { SSC } \\
\left({ }^{\circ} \text { Brix }\right)\end{array}$ & $\begin{array}{c}\text { TA } \\
\left(\text { MAE L }^{-1}\right)\end{array}$ & $\begin{array}{c}\text { Firmness } \\
\left(\mathrm{kg} \mathrm{cm}^{-2}\right)\end{array}$ & $\mathrm{pH}$ \\
\hline 'Nesta' & $16.3 \pm 0.6$ & $10.3 \pm 1.7^{\mathrm{B}}$ & $3.5 \pm 0.5^{\mathrm{B}}$ & $3.8 \pm 0.0^{\mathrm{B}}$ \\
'Panaia-red' & $14.0 \pm 2.5$ & $13.6 \pm 2.4^{\mathrm{A}}$ & $3.2 \pm 0.2^{\mathrm{B}}$ & $3.3 \pm 0.1^{\mathrm{C}}$ \\
'Cipolla' & $14.0 \pm 0.0$ & $4.3 \pm 1.1^{\mathrm{C}}$ & $3.7 \pm 0.6^{\mathrm{B}}$ & $4.1 \pm 0.3^{\mathrm{A}}$ \\
'Golden Delicious' & $15.0 \pm 1.0$ & $13.2 \pm 0.8^{\mathrm{AB}}$ & $5.0 \pm 0.3^{\mathrm{A}}$ & $3.5^{\mathrm{C}} \pm .1^{\mathrm{C}}$ \\
\hline$P$ values & n.s. & $* * *$ & $* *$ & $* * *$ \\
\hline
\end{tabular}

Values are the means $\pm \mathrm{SD}(n=3)$. Data were analysed by ANOVA followed by LSD post-hoc test $(* *, P \leqslant 0.01 ; * * *, P<0.001 ;$ n.s., not significant). In the same column, different letters indicate significant differences between cultivars according to LSD-test at $P=0.05$.

\subsection{ROS measurements}

ROS production was evaluated by ROS-sensitive fluorescent probe 5-(and-6)-chloromethyl-20,70-dichloro-dihydro-fluorescein diacetate, acetyl ester (CM-H2DCFDA) (Invitrogen). Briefly, after treatment, HUVEC were washed with PBS and incubated with CMH2DCFDA (10 $\mu \mathrm{M}$ well $\left.{ }^{-1}\right)$ for $30 \mathrm{~min}$ at RT in the dark. Then cells were washed twice with fresh pre-warmed PBS, and ROS production was detected in HUVEC by measuring the increase in fluorescence by microplate reader. Fluorescence was measured by excitation at $488 \mathrm{~nm}$ and emission at $510 \mathrm{~nm}$.

\subsection{Statistical analyses}

All results were reported as means \pm standard deviation (SD). For each parameter, three analytical determinations were carried out and then averaged on each independent biological replication. The difference among groups was evaluated by a one-factor ANOVA test and post-hoc comparison test run at $P \leqslant 0.05$.

\section{Results and discussion}

\subsection{Fruit physiological parameters}

The quality of apples is measured by basic pomological descriptors, such as size, colour, soluble solid content, titratable acidity and firmness. Regarding fruits colour, all fruits of 'Nesta', 'Panaia-red' and 'Cipolla' cultivars had part of their skin red. In addition, 'Cipolla' fruit had also red streaks in flesh. 'Golden Delicious' fruit had yellow skin with only few red streaks. Regarding fruit firmness, 'Golden Delicious' had the highest value $\left(5.0 \pm 0.34 \mathrm{~kg} \mathrm{~cm}^{-2}\right)$. Other fruits had lower and similar values ('Panaia-red' $3.2 \pm 0.23 \mathrm{~kg} \mathrm{~cm}^{-2}$; 'Nesta' $3.5 \pm 0.54 \mathrm{~kg} \mathrm{~cm}^{-2}$; 'Cipolla' $3.7 \pm 0.55 \mathrm{~kg} \mathrm{~cm}^{-2}$ ) (table I). SSC, $\mathrm{pH}$ and TA are quality parameters related to the stability of bioactive compounds in fruits and their derived products, and were determined in fruits and in juices immediately after their production. The amount of SSC was similar among all the four apple varieties and was in the range of $14.0 \pm 0.01$ to $16.3 \pm 0.58$. 'Cipolla' fruit had the highest value of $\mathrm{pH}(4.1 \pm 0.25)$, whereas 'Panaia-red' and 'Golden
Delicious' fruits had the lowest $(3.3 \pm 0.09$ and $3.5 \pm 0.08$, respectively). 'Nesta' fruit had an intermediate value $(3.8 \pm 0.03)$ (table I).

Juice yield from fresh fruits is strongly affected by cultivar, fruit phenological stage, and juice production method [24]. In our case it ranges from $60 \%(\mathrm{v} / \mathrm{w})$ for 'Nesta', $58 \%(\mathrm{v} / \mathrm{w})$ for 'Panaia-red', 30\% (v/w) for 'Cipolla' and $50 \%(\mathrm{v} / \mathrm{w})$ for 'Golden Delicious'.

\subsection{Apple juice polyphenolic and ascorbic acid contents}

Oxidative stress is involved in different cardiovascular diseases. Polyphenols, secondary plant metabolites, are able to contrast this kind of stress [25]. Apples and apple products are a good source of polyphenols, particularly in some ancient cultivars the "high polyphenol content" trait can be present [8].

Table II showed TP and TF and ascorbic acid concentrations of 'Nesta', 'Panaia-red', 'Cipolla' and 'Golden Delicious' juices after production and after pasteurization and four weeks of storage at RT, respectively. 'Panaia-red' juice had a higher phenolic concentration than the other juices, both after preparation and after pasteurization and storage at RT: 2.26-, 5.14- and 1.87-fold higher for TP, and 4.80-, 8.28- and 2.59fold higher for TF in respect to 'Nesta', 'Cipolla' and 'Golden Delicious' juices after preparation and 2.05-, 2.23- and 1.32fold higher for TP, and 4.20-, 7.19- and 2.08-fold higher for TF in respect to 'Nesta', 'Cipolla' and 'Golden Delicious' juices after pasteurization and storage at RT. Moreover, TP and TF content of 'Golden Delicious' were significantly higher compared to 'Nesta' and 'Cipolla' juices.

In a previous research, Iacopini et al. [8] characterized the phenolic content and evaluated the antioxidant activity of four ancient Italian apple cultivars ('Nesta', 'Panaia-red', 'Ruggine' and 'Mora') in comparison with two commercial cultivars ('Golden Delicious' and 'Stark Delicious'). In that research, the authors analyzed the TP and TF of the whole apple fruits. Although the units of measurement are different (phenol content per fruit FW vs. juice volume), the results showed that 'Panaia-red' was the one with the highest amount of TP and TF [8]. In an our previous work we analyzed the phenolic concentration and the antioxidant activity of 'Panaiared' and 'Golden Delicious' juices after preparation and after two weeks of storage at different conditions [26]. Also in 
Table II. Total phenols, total flavonoids and ascorbic acid of 'Nesta', 'Panaia-red', 'Cipolla' and 'Golden Delicious' apple juices after production and after 4 weeks of storage at room temperature after pasteurization (GAE: Gallic Acid Equivalent; CE: Catechin Equivalent; RT: Room temperature).

\begin{tabular}{|c|c|c|c|}
\hline & $\begin{array}{l}\text { Total phenols } \\
\left(\mathrm{mg} \mathrm{GAE} \mathrm{L}^{-1}\right)\end{array}$ & $\begin{array}{l}\text { Total flavonoids } \\
\left(\mathrm{mg} \mathrm{CE} \mathrm{L}^{-1}\right)\end{array}$ & $\begin{array}{l}\text { Ascorbic acid } \\
\left(\mathrm{mg} \mathrm{L}^{-1}\right)\end{array}$ \\
\hline \multicolumn{4}{|c|}{ Apple Juice after preparation } \\
\hline 'Nesta' & $1,580.0 \pm 32.1^{\mathrm{C}}$ & $382.2 \pm 31.4^{\mathrm{C}}$ & $21.7 \pm 0.7^{\mathrm{A}}$ \\
\hline 'Panaia-red' & $3,573.9 \pm 81.7^{\mathrm{A}}$ & $1839.0 \pm 45.0^{\mathrm{A}}$ & $21.6 \pm 0.4^{\mathrm{A}}$ \\
\hline 'Cipolla' & $695.5 \pm 6.5^{\mathrm{D}}$ & $222.2 \pm 15.8^{\mathrm{C}}$ & $11.9 \pm 0.1^{\mathrm{C}}$ \\
\hline 'Golden Delicious' & $1,908.9 \pm 23.9^{\text {B }}$ & $709.1 \pm 5.0^{\mathrm{B}}$ & $18.3 \pm 0.1^{\mathrm{B}}$ \\
\hline$P$ values & $* * *$ & $* * *$ & $* * *$ \\
\hline \multicolumn{4}{|c|}{$\begin{array}{l}\text { Apple Juice after pasteurization } \\
\text { and storage }\left(4 \text { weeks at } \mathrm{RT}^{\mathrm{c}}\right)\end{array}$} \\
\hline 'Nesta' & $2,080.8 \pm 177.8^{\mathrm{C}}$ & $628.0 \pm 91.7^{\mathrm{C}}$ & $21.0 \pm 1.3^{\mathrm{B}}$ \\
\hline 'Panaia-red' & $4,274.6 \pm 250.2^{\mathrm{A}}$ & $2,632.0 \pm 273.8^{\mathrm{A}}$ & $32.1 \pm 9.0^{\mathrm{A}}$ \\
\hline 'Cipolla' & $1,918.9 \pm 0.0^{\mathrm{C}}$ & $366.9 \pm 24.8^{\mathrm{C}}$ & $14.5 \pm 2.0^{\mathrm{B}}$ \\
\hline 'Golden Delicious' & $3,241.5 \pm 548.3^{\text {B }}$ & $1,268.8 \pm 110.9^{\mathrm{B}}$ & $19.0 \pm 0.3^{\mathrm{B}}$ \\
\hline$P$ values & $* * *$ & $* * *$ & $* * *$ \\
\hline
\end{tabular}

Values are the means $\pm \mathrm{SD}(n=3)$. Data were analysed by ANOVA followed by LSD post-hoc test $(* * *, P \leqslant 0.001)$. In the same column, different letters indicate significant differences between cultivars according to LSD-test at $P=0.05$.

Table III. Procyanidin $\mathrm{B}_{1}$, (+)-catechin, (-)-epicatechin, phloridzin, neo-chlorogenic acid and chlorogenic acid concentration of 'Nesta', 'Panaia-red', 'Cipolla' and 'Golden Delicious' apple juices after production and after 4 weeks of storage at room temperature after pasteurization (RT: Room temperature; n.d. not detected).

\begin{tabular}{|c|c|c|c|c|c|c|}
\hline & \multicolumn{6}{|c|}{ Phenolic contents $\left(\mathrm{mg} \mathrm{L}^{-1}\right)$} \\
\hline & Procyanidin $\mathrm{B}_{1}$ & $(+)$-Catechin & (-)-Epicatechin & Phloridzin & $\begin{array}{l}\text { Neo-chlorogenic } \\
\text { acid }\end{array}$ & $\begin{array}{l}\text { Chlorogenic } \\
\text { acid }\end{array}$ \\
\hline 'Nesta' & $23.5 \pm 4.1^{\mathrm{C}}$ & $33.1 \pm 2.0^{\mathrm{B}}$ & $41.0 \pm 1.8^{\mathrm{B}}$ & $45.6 \pm 3.4^{\mathrm{BC}}$ & $0.7 \pm 0.2$ & $521.5 \pm 33.8^{\mathrm{C}}$ \\
\hline 'Panaia-red' & $114.9 \pm 1.2^{\mathrm{A}}$ & $57.1 \pm 5.8^{\mathrm{A}}$ & $65.5 \pm 2.8^{\mathrm{A}}$ & $106.0 \pm 28.6^{\mathrm{A}}$ & n.d. & $1,183.3 \pm 27.4^{\mathrm{A}}$ \\
\hline 'Cipolla' & n.d. & $31.6 \pm 1.4^{\mathrm{B}}$ & $28.2 \pm 1.4^{\mathrm{C}}$ & $15.3 \pm 2.1^{\mathrm{C}}$ & $1.2 \pm 0.3$ & $452.8 \pm 45.4^{\mathrm{C}}$ \\
\hline$P$ values & $* * *$ & $* * *$ & $* * *$ & $*$ & ns & $* * *$ \\
\hline \multicolumn{7}{|c|}{$\begin{array}{l}\text { Apple Juice after pasteurization } \\
\text { and storage ( } 4 \text { weeks at } \mathrm{RT}^{\mathrm{a}} \text { ) }\end{array}$} \\
\hline 'Nesta' & $67.7 \pm 4.3^{\mathrm{B}}$ & $45.8 \pm 9.6^{\mathrm{B}}$ & $59.7 \pm 3.2^{\mathrm{B}}$ & $88.4 \pm 5.8^{\mathrm{B}}$ & $2.7 \pm 0.3$ & $786.8 \pm 50.8^{\mathrm{B}}$ \\
\hline 'Panaia-red' & $150.9 \pm 12.0^{\mathrm{A}}$ & $67.5 \pm 4.8^{\mathrm{A}}$ & $81.3 \pm 4.8^{\mathrm{A}}$ & $114.3 \pm 16.3^{\mathrm{A}}$ & n.d. & $1,213.3 \pm 73.1^{\mathrm{A}}$ \\
\hline
\end{tabular}

Values are the means $\pm \mathrm{SD}(n=3)$. Data were analysed by ANOVA followed by LSD post-hoc test (ns $=$ not significant $*, P \leqslant 0.05$; $* * *, P \leqslant 0.001)$. In the same column, different letters indicate significant differences between cultivars according to LSD-test at $P=0.05$.

that research 'Panaia-red' juices had the highest concentrations of TP and TF. Moreover, the phenolic profiles of juices were investigated by HPLC. (+)-catechin, (-)-epicatechin, procyanidin $\mathrm{B}_{1}$, chlorogenic acid, neochlorogenic acid and phloridzin concentrations were analyzed in both juices after production and after pasteurization (table III). Chlorogenic acid was the main compound in all the juices. Concerning juices after preparation, 'Panaia-red' juice had the highest concentration for all compounds analyzed, except for neochlorogenic acid that was not detected. 'Golden Delicious' juice had a good concentration of chlorogenic acid, phloridzin and procyanidin $\mathrm{B}_{1}$ compared to 'Nesta' and 'Cipolla' AJ and the lowest concentration of (-)-epicatechin. (+)-Catechin and neochlorogenic acid were absent. 'Nesta' and 'Cipolla' juices had the lowest concentrations of phloridzin and chlorogenic acid, but the highest of neochlorogenic acid. Procyanidin $\mathrm{B}_{1}$ was completely absent in 'Cipolla' juice, whereas it had an intermediate concentration in the 'Nesta' one. As in 'Panaia-red' and 'Golden Delicious' juices analyzed after preparation, the concentrations of neochlorogenic acid were not detected also in the juices analyzed after pasteurization and storage at RT. The same was for (+)-catechin concentration in 'Golden Delicious' juice. Also 'Cipolla' juice after pasteurization and storage had not (+)-catechin, but it was possible to detect procyanidin $\mathrm{B}_{1}$. 
(-)-Epicatechin concentration was stable. We supposed that during pasteurization and storage a (+)-catechin metabolization and polymerization might occur. Generally, $(+)$-catechin is a good substrate of polyphenol oxydase (PPO) in the presence of oxygen [27], but during pasteurization this enzyme is inactivated, preserving the (+)-catechin content of juices, as shown in our previous work [26]. Finally, it was shown that after pasteurization and storage chlorogenic acid and phloridzin increased in 'Nesta' juice for $33.7 \%$ and $48.4 \%$, respectively, procyanidin $\mathrm{B}_{1}$ increased for $65.3 \%$ in 'Nesta', $23.9 \%$ in 'Panaia-red' and $100 \%$ in 'Cipolla' juices, neochlorogenic acid increased for $72.8 \%$ in 'Nesta' and 50.4\% in 'Cipolla' juices, (-)-epicatechin increased for $31.4 \%$ in 'Nesta' and $19.4 \%$ in 'Panaia-red' juices, whereas (+)-catechin decrease dramatically in 'Cipolla' juice (100\%). In comparison with our previous work, all AJ had a higher concentration of chlorogenic acid, even through the storage time was longer (four weeks, instead of two weeks). On the contrary (+)-catechin and (-)-epicatechin concentrations were lower. Phloridzin concentration was comparable [26]. The different concentrations of some phenolic compounds found, might be explained by the different harvest year and climatic conditions.

Other researchers studied the phenolic profile of AJ produced by several commercial and different old varieties [28-30]. Kahle et al. [28] investigated the phenolic compounds of AJ produced by 4 commercial and 7 German apple varieties; Markowski et al. [29] studied the chemical composition of AJ produced by French and Polish varieties and Lanzerstorfer et al. [30] characterized the phenolic profiles of 88 AJ produced by Austrian varieties. Chlorogenic acid was the main compound found in all $\mathrm{AJ}$, in accordance with our results. (+)-Catechin concentrations were higher in 'Belle de Boskoop' apple juice and other commercial cloudy apple juices than 'Cipolla' and 'Golden Delicious' ones. Phloridzin and (-)-epicatechin concentrations were comparable with juices produced by French and Polish varieties. Chlorogenic acid and procyanidin $\mathrm{B}_{1}$ concentrations of 'Panaiared', 'Golden Delicious', 'Nesta' and 'Cipolla' juices were higher than German, French and Polish apple juices [28, 29]. Chlorogenic acid concentration of 'Panaia-red' AJ was comparable to 'Harberts Renette' AJ, an Austrian apple variety (1,213.3 $\mathrm{mg} \mathrm{L}^{-1}$ for 'Panaia-red' AJ vs. $1,209.2 \mathrm{mg} \mathrm{L}^{-1}$ for 'Harberts Renette' AJ) [30]. The differences in water solubility between the different flavonoid groups and the chlorogenic acid might explain that only a fraction of other phenolic compounds are extracted into the juice. The rest remains in the pomace $[24,26]$. Chlorogenic acid is the most water-soluble compound and specially located in apple flesh. This might explain also the highest yield for this compound in the juice. For our knowledge it was the first time that neo-chlorogenic acid concentrations were quantified in 'Nesta' and 'Cipolla' juices. However, since the juices produced are cloudy juices, it might be possible that during pasteurization some extractive reactions from the solid phase and polymerization were occurred. Finally, it was observed that, among the investigated apple varieties, old varieties more often had more polyphenols than commercial apple varieties.

Concerning ascorbic acid concentrations of juices after production, 'Panaia-red' and 'Nesta' juices had the highest
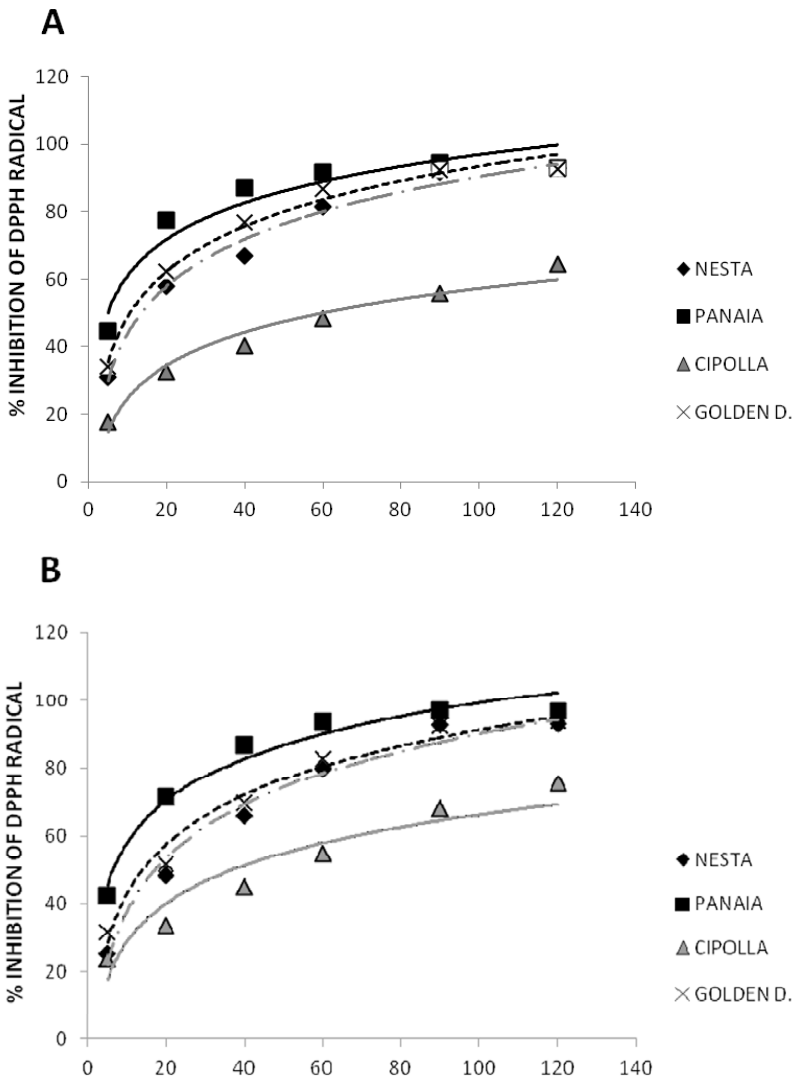

Figure 1. Inhibition percentages of DPPH radical in: (A) apple juice after production, (B) apple juice after pasteurization and four weeks of storage. Logarithmic curves \{percentage of inhibition of DPPH $=$ $(\mathrm{a} \times \ln (\mathrm{t})+\mathrm{b})\}$ in the graph represent different apple varieties.

values $\left(21.6 \pm 0.4 \mathrm{mg} \mathrm{L}^{-1}\right.$ and $21.7 \pm 0.7 \mathrm{mg} \mathrm{L}^{-1}$, respectively), 'Golden Delicious' juice had an intermediate value $\left(18.3 \pm 0.1 \mathrm{mg} \mathrm{L}^{-1}\right)$, whereas 'Cipolla' juice had the lowest $\left(11.9 \pm 0.1 \mathrm{mg} \mathrm{L}^{-1}\right)$. On the other hand, only 'Panaia-red' juice after pasteurization and stored at RT revealed a significantly higher content of ascorbic acid compared to 'Nesta', 'Cipolla' and 'Golden Delicious' AJ (table II). Furthermore, ascorbic acid resulted to be stable after the pasteurization and the storage of AJ. However, especially for AJ, it was demonstrated that their antioxidant activity can be accounted for essentially by chlorogenic acid and other compounds in lower concentrations, such as phloridzin and epicatechin and only in a little part for ascorbic acid [31,32].

\subsection{Antioxidant activity and effect of apple juice on HUVEC viability}

The AJ scavenging ability towards the DPPH assay is reported in figure 1. After $120 \mathrm{~min}$ of reaction, the inhibition percentages of DPPH radical (DDPH') was measured for all juices, after preparation and after pasteurization and storage at RT. The inhibition percentages showed statistical differences for the four cultivars. Considering AJ after production, 'Panaia-red', 'Nesta' and 'Golden Delicious' had similar inhibition percentages (93\% inhibition DPPH'), whereas 'Cipolla' juice had the lowest value ( $65 \%$ inhibition DPPH'). A different 


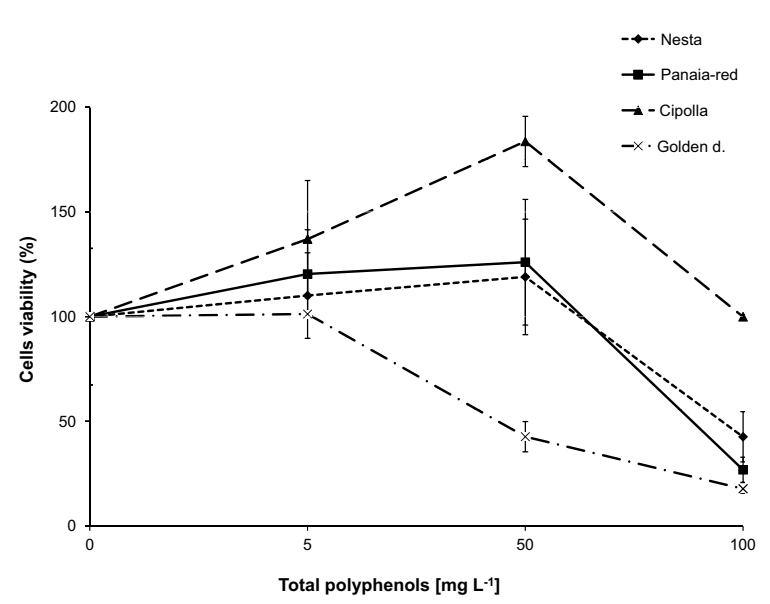

Figure 2. Dose-dependent cell viability. HUVEC cells were cultured for $24 \mathrm{~h}$ in the presence of 'Nesta', 'Panaia-red', 'Cipolla' and 'Golden Delicious' apple juice varieties (from $5 \mathrm{mg} \mathrm{L}^{-1}$ up to $100 \mathrm{mg} \mathrm{L}^{-1}$ of total polyphenols). Cell viability was determined by WST-1 colorimetric assay and expressed as \% viability compared to control (untreated cells). Data are representative of three separate experiments in triplicate.

scenario was seen, when juices after pasteurization and storage were analyzed. 'Panaia-red' juice showed the highest value, with 97\% inhibition DPPH. This was in accordance with our previous work [26]. 'Golden Delicious' and 'Nesta' AJ had also a good antioxidant activity with $94 \%$ and $93 \%$ inhibition DPPH', respectively. The 'Cipolla' juice showed always a lower level of antioxidant activity with respect to the other three juices (75\% inhibition DPPH ${ }^{\circ}$.

To evaluate the antioxidant activity of $\mathrm{AJ}$ another in vitro test was carried on: HUVEC cell culture. This test was performed only on the pasteurized AJ, being richer in polyphenols. Endothelial cells, isolated from a pool of human umbilical cords, are commonly used as cell culture model to understand the mechanisms of cardiovascular diseases in vitro. For that reason, we chose HUVEC model to investigate the protective effect of $\mathrm{AJ}$ obtained from ancient cultivars against oxidative stress induced by $\mathrm{H}_{2} \mathrm{O}_{2}$.

Since cell viability can be modified by exogenous addition of compounds [33] and to determine non-toxic concentration of 'Nesta', 'Panaia-red', 'Cipolla' and 'Golden Delicious' apple variety juices, we preliminary incubated HUVEC in the presence of three different concentrations of TP AJ $(5,50$ and $\left.100 \mathrm{mg} \mathrm{L}^{-1} \mathrm{TP}\right)$. Dose-dependent HUVEC viability indicated that no significant cytotoxic effects were observed at AJ concentrations below $50 \mathrm{mg} \mathrm{L}^{-1}$ TP. On the other hand, a significant decrease of cell viability (57\%) was observed for 'Golden Delicious' juice at concentrations equivalent to $50 \mathrm{mg} \mathrm{L}^{-1} \mathrm{TP}$ and at AJ concentrations equivalent to $100 \mathrm{mg} \mathrm{L}^{-1} \mathrm{TP}$. Only 'Cipolla' juice does not appear toxic at different concentration of TP (figure 2). According to these results, the concentration of $5 \mathrm{mg} \mathrm{L}^{-1} \mathrm{TP}$ was used for the successive experiments.

\subsection{ROS accumulation}

Figure 3 shows AJ effect on ROS accumulation in HUVECs as determined by CM-H2DCFDA, a cell-permeable indicator for these compounds. Treatment with $\mathrm{H}_{2} \mathrm{O}_{2}$ induces an increase in ROS production compared to untreated cell (control) $(P<0.01)$. All juices did not induce ROS production after $24 \mathrm{~h}$ of incubation. Finally, $24 \mathrm{~h}$ pre-incubation with 'Panaia-red' juice, as well as 'Golden Delicious' juice, attenuated excessive reactive oxygen species production in $\mathrm{HU}$ VEC exposed to $\mathrm{H}_{2} \mathrm{O}_{2}$ compared to cells treated with $\mathrm{H}_{2} \mathrm{O}_{2}$ without AJ pre-treatment $(P<0.001$ and $P<0.01$, respectively). 'Panaia-red' and 'Golden Delicious' AJ showed a significant decrease of ROS production, in accordance with Gong et al. [34], that investigated the effects of rutin, an important apple flavonoid, on HUVEC stressed by $\mathrm{H}_{2} \mathrm{O}_{2}$ [34]. This specific phenolic molecule could attenuate intracellular ROS levels, protecting HUVECs from apoptosis induced by $\mathrm{H}_{2} \mathrm{O}_{2}$.

\subsection{Protective effect from oxidative stress of apple juice}

To evaluate the $\mathrm{H}_{2} \mathrm{O}_{2}$ concentration reducing $50 \%$ cell viability (IC50), HUVEC were treated for $1 \mathrm{~h}$ with different concentration of $\mathrm{H}_{2} \mathrm{O}_{2}$ (from 0.01 to $4.00 \mathrm{mM}$ ). Cell viability was significantly reduced by $2 \mathrm{mM} \mathrm{H}_{2} \mathrm{O}_{2}(P<0.001)$ (data not shown). As shown in figure 4 , after $24 \mathrm{~h}$ pre-incubation only 'Panaia-red' $\mathrm{AJ}$ ( $\left.5 \mathrm{mg} \mathrm{L}^{-1} \mathrm{TP}\right)$, prevented $2 \mathrm{mM} \mathrm{H}_{2} \mathrm{O}_{2}$ induced reduction of viable cell number $(P<0.05)$, having a protective effect on HUVEC. This may be due to its high concentration of TP and TF compared to those of 'Golden Delicious'.

Recently, it has been demonstrated that polyphenols obtained by pre-maturity red grape seed extract improve the resistance of endothelial cells to oxidative stress [35]. Several studies were conducted analysing a single antioxidant compound of a specific fruit or vegetable on HUVEC or other cells model stressed by $\mathrm{H}_{2} \mathrm{O}_{2}$ or other oxidative agent. In our research we wanted to study the whole antioxidant capacity of $\mathrm{AJ}$ produced by different cultivars, and not a single compound, on HUVEC.

It is also important to underline that the absorption of polyphenols in the human body is complex and still under investigation. Although aglycones can be absorbed from the small intestine, most polyphenols are present in food in other forms, such as esters, glycosides, or polymers that may not be absorbed. These kinds of substance are usually hydrolyzed by intestinal enzymes or by the colonic microflora before their absorption $[1,36]$. For example, $(+)$-catechin and (-)-epicatechin are absorbed by small intestinal epithelial cells and they are sulphated by the human liver and intestinal citosol, demonstrating that sulfation is the major pathway for their metabolism [37]. At the end of the metabolic pathway, polyphenols and their derivatives are eliminated in urine and bile. However, all metabolites contribute to increase the antioxidant levels in plasma. A high antioxidant level, especially in the colon, is very important for the anticancer effect [1].

A clinical trial was carried out to verify the improvement of serum antioxidant status in humans after an acute intake of AJ produced by two different cultivars, 'Golden Delicious' and 'Catarina', a Brazilian variety was done by Vieira et al. [38]. These authors demonstrated that $\mathrm{AJ}$ consumption increased 


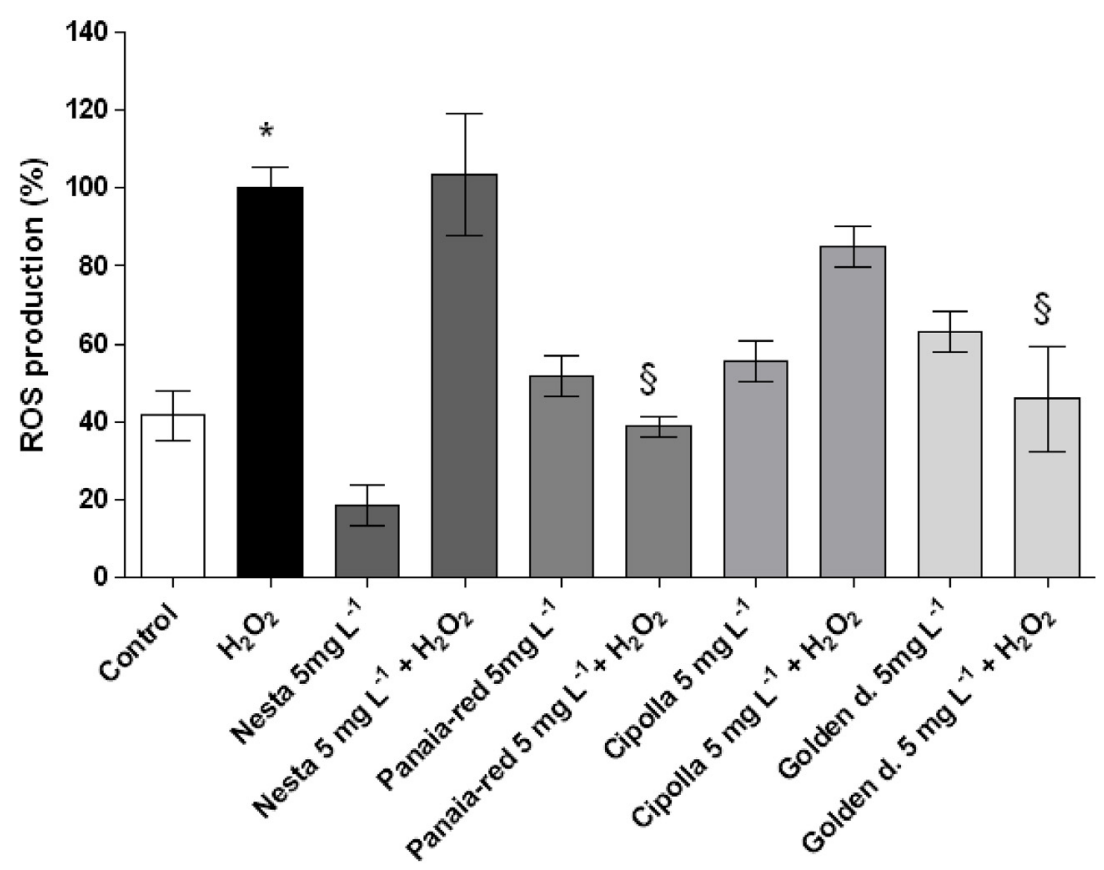

Figure 3. Effects of apple juice on ROS accumulation in HUVEC. ROS production was determined by fluorimetric assay (Exc.488 nm/Em. $510 \mathrm{~nm}$ ). Cells were pre-treated for $24 \mathrm{~h}$ with $5 \mathrm{mg} \mathrm{L}^{-1}$ of different apple juices and then with $2 \mathrm{mM} \mathrm{H}_{2} \mathrm{O}_{2}$ for $1 \mathrm{~h}$. Results are expressed as mean \pm SD of 3 independent experiments. Differences were analysed by one-way ANOVA test. $* * P<0.01 v s$. Control and $\S P<0.001 v s$. $\mathrm{H}_{2} \mathrm{O}_{2}$.

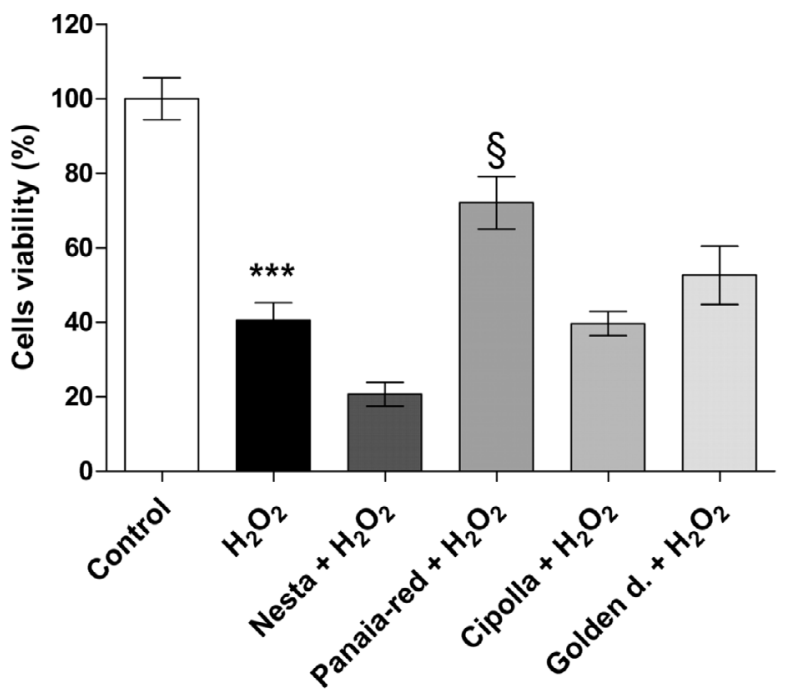

Figure 4. Protective effect of apple juice. HUVEC viability was evaluated after $24 \mathrm{~h}$ of incubation with apple juice $\left(5 \mathrm{mg} \mathrm{L}^{-1}\right.$ of total polyphenols) and $2 \mathrm{mM} \mathrm{H}_{2} \mathrm{O}_{2}$ for $1 \mathrm{~h}$. Data are expressed as $\%$ viability compared to control (untreated cells) and are representative of 3 separate experiments in triplicate. Differences were analysed by one-way ANOVA test. $* * * P<0.001 v s$. Control; $\S P<0.05$ vs. $\mathrm{H}_{2} \mathrm{O}_{2}$.

the serum antioxidant capacity and decreased the biomarkers of lipid peroxidation, although the in vitro antioxidant capacity of AJ could not be reproduced exactly in an in vivo study, because of polyphenol digestion in the human body [38].

\section{Conclusion}

Freshly made and pasteurized and stored apple juices (AJ) were shown good sources of nutraceutical compounds. Six of the most representative phenolic compounds were investigated on their changes after pasteurization and storage at room temperature. Ascorbic acid was quantified and its levels were low in comparison to polyphenols, especially for 'Cipolla' AJ. 'Panaia-red' juices had the highest concentrations of polyphenols after preparation and after pasteurization and storage. However, every phenolic compound increased its concentration in 'Nesta' AJ after pasteurization and storage. Pasteurized AJ proved to have significant antioxidant capacity on $\mathrm{HU}$ VECs stressed by $\mathrm{H}_{2} \mathrm{O}_{2}$, but the genetic component is a crucial aspect of this activity. 'Panaia-red' juice showed the highest antioxidant performance. The results of our research could be useful to address future studies on $\mathrm{AJ}$ antioxidant properties addressing the research focus on selected apple genotypes particularly rich in phenolic compounds.

\section{References}

[1] Scalbert A., Williamson G., Dietary intake and bioavailability of polyphenols, J. Nutr. 130 (2000) 2073-2085.

[2] Boyer J., Liu R.H., Apple phytochemicals and their health benefits, Nutr. J. 3 (2004) 5.

[3] Liu R.H., Health-promoting components of fruits and vegetables in the diet, Adv. Nutr. 4 (2013) 384S-392S.

[4] Ross R., Atherosclerosis-an inflammatory disease, N. Engl. J. Med. 340 (1999) 115-126.

[5] Sinha K., Das J., Pal P.B., Sil P.C., Oxidative stress: the mitochondria-dependent and mitochondria-independent pathways of apoptosis, Arch. Toxicol. 87 (2013) 1157-1180. 
[6] Dejana E., Spagnuolo R., Bazzoni G., Interendothelial junctions and their role in the control of angiogenesis, vascular permeability and leukocyte transmigration, Thromb. Haemost. 86 (2001) 308-315.

[7] Panzella L., Petriccione M., Rega P., Scortichini M., Napolitano A., A reappraisal of traditional apple cultivars from Southern Italy as a rich sourece of phenols with superior antioxidant activity, Food Chem. 140 (2013) 672-679.

[8] Iacopini P., Camangi F., Stefani A., Sebastiani L., Antiradical potential of ancient Italian apple varieties of Malus $x$ domestica Borkh. in a peroxynitrite-induced oxidative process, J. Food Compos. Anal. 23 (2010) 518-524.

[9] Wojdylo A., Oszmianski J., Laskowski P., Polyphenolic compounds and antioxidant activity of new and old apple varieties, J. Agric. Food Chem. 56 (2008) 6520-6530.

[10] Francini A., Sebastiani L., Phenolic compounds in apple (Malus $x$ domestica Borkh.): Compounds characterization and stability during postharvest and after processing, Antioxidants 2 (2013) 181-193.

[11] Vinson J.A., Su X., Zubik L., Bose P., Phenol antioxidant quantity and quality in foods: fruits, J. Agric. Food Chem. 49 (2001) 5315-5321.

[12] Yuan L., Meng L., Ma W., Xiao Z., Zhu X., Feng J.F., Yu H., Xiao R., Impact of apple and grape juice consumption on the antioxidant status in healthy subjects, Int. J. Food Sci. Nutr. 62 (8) (2011) 844-850.

[13] Koch T.C., Briviba K., Watzl B., Fahndrich C., Bub A., Rechkemmer G., et al. Prevention of colon carcinogenesis by apple juice in vivo: impact of juice constituents and obesity, Mol. Nutr. Food Res. 53 (2009) 1289-1302.

[14] Gallus S., Talamini R., Giacosa A., Montella M., Ramazzotti V., Franceschi S., et al. Does an apple a day keep the oncologist away?, Ann. Oncol. 16 (2005) 1841-1844.

[15] Gerhauser C., Cancer chemopreventive potential of apples, apple juice, and apple components, Planta Med. 74 (2008) 1608-1624.

[16] Schrenk D., Apple juice and intestinal health, Mol Nutr Food Res 53 (2009) 1209.

[17] Minnocci A., Iacopini P., Martinelli F., Sebastiani L., Micromorphological, Biochemical, and genetic characterization of two ancient, late-bearing apple varieties, Eur. J. Hort. Sci. 75 (2010) 1-7.

[18] Gallesio G., Pomona Italiana, ossia trattato degli alberi da frutto, N. Capurro, Pisa 1817-1839.

[19] Camangi F., Stefani A., Segantini L., Seravelli M., Eds., Alla riscoperta della frutta antica del Casentino. Un patrimonio agroalimentare di alto pregio genetico, culturale ed economico, Edizioni ETS, Pisa, 2013.

[20] Conservation of and adding of value to the patrimony of local breeds and varieties Tuscany. Regione Toscana, 2010.

[21] Singleton V.L., Orthofer R., Lamuela-Raventos R.M., Analysis of total phenols and other oxidation substrates and antioxidants by means of Folin-Ciocalteu Reagent, Methods Enzymol. 299 (1999) 152-178.

[22] Kim H.Y., Kang M.H., Flavonoid content of some Korean medicinal plants, Food Sci Biotech 12 (2003) 687-690.
[23] Brand-Williams W., Cuvelier M.E., Berset C. Use of a free radical method to evaluate antioxidant activity, LWT - Food Sci. Technol. 28 (1995) 25-30.

[24] Van der Sluis, A.A., A chain analysis of the production of 'healthy' apple juice. The case of polyphenolic antioxidants. Wageningen University, The Netherlands, PhD Thesis, 2005.

[25] Felice F., Zambito Y., Di Colo G., D’Onofrio C., Fausto C., Balbarini A., et al. Red grape skin and seeds polyphenols: Evidence of their protective effects on endothelial progenitor cells and improvement of their intestinal absorption, Eur. J. Pharm. Biopharm. 80 (2012) 176-184.

[26] Maragò E., Iacopini P., Camangi F., Scattino C., Ranieri A., Stefani A., Sebastiani L., Phenolic profile and antioxidant activity in juice and pomace of apples: effects of different storage conditions, Fruits 70 (4) (2015) 213-223.

[27] Spanos G.A., Wrolstad R.E., Heatherbell D.A., Influence of processing and storage on the phenolic composition of apple juice, J. Agric. Food Chem. 38 (1990) 1572-1579.

[28] Kahle K., Kraus M., Richling, E., Polyphenol profiles of apple juices, Mol. Nutr. Food Res. 49 (2005) 797-806.

[29] Markowski J., Baron A., Mieszczakowaka M., Płocharski W., Chemical composition of French and Polish cloudy apple juices, J. Hortic. Sci. Biotech. Special issue (2009) 68-74.

[30] Lanzerstofer P., Wruss J., Humer S., Steininger A., Muller U., et al. Bioanalytical characterization of apple juice from 88 grafted and nongrafyed apple varieties grown in Upper Austria, J. Agric. Food. Chem. 62 (2014) 1047-1056.

[31] Miller N.J., Diplock A.T., Rice-Evans C.A., Evaluation of the total antioxidant activity as a marker of the deterioration of apple juice on storage, J. Agric. Food Chem. 43 (1995) 1794-1801.

[32] Miller N.J., Rice-Evans C.A., The relative contributions of ascorbic acid and phenolic antioxidants to the total antioxidant activity of orange and apple fruit juices and blackcurrant drink, Food Chem. 60 (1997) 331-337.

[33] Nohl H., Kozlov A.V., Gille L., Staniek K., Cell respiration and formation of reactive oxygen species: facts and artefacts, Biochem. Soc. Transact. 31 (2003) 1308-1311.

[34] Gong G., Qin Y., Huang W., Zhou S., Yang X., Li D., Rutin inhibits hydrogen peroxide-induced apoptosis through regulating reactive oxygen species mediated mitochondrial dysfunction pathway in human umbilical vein endothelial cells, Eur. J. Pharmacol. 628 (2010) 27-35.

[35] Felice F., Zambito Y., Belardinelli E., D’Onofrio C., Fabiano A., Balbarini A., et al. Delivery of natural polyphenols by polymeric nanoparticles improves the resistance of endothelial progenitor cells to oxidative stress, Eur. J. Pharm. Sci. 50 (2013) 393-399.

[36] Manach C., Scalbert A., Morand C., Remesy C., Jimenez L., Polyphenols: food sources and bioavailability, Am. J. Clin. Nutr. 79 (2004) 727-747.

[37] Vaidyanathan J., Walle T., Glucuronidation and sulfaation of the tea flavonoid (-) epicatechin by the human and rat enzumes, Drug Metab. Dispos. 30 (2002) 897-903.

[38] Vieira F.G., Di Pietro P.F., da Silva E.L., Borges G.S., Nunes E.C., Fett R., Improvement of serum antioxidant status in humans after the acute intake of apple juices, Nutr. Res. 32 (2012) 229-232. 